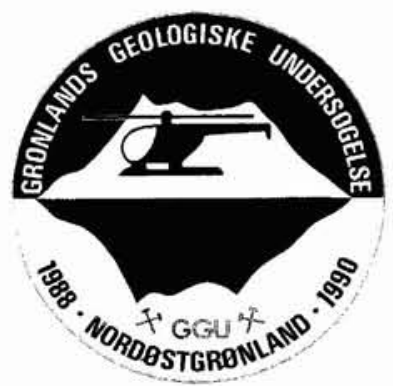

\title{
Age and origin of Caledonian granites in the Grandjean Fjord - Bessel Fjord region $\left(75^{\circ}-76^{\circ} \mathrm{N}\right)$, North-East Greenland
}

\author{
Bent T. Hansen, Niels Henriksen \\ and Feiko Kalsbeek
}

\begin{abstract}
The Grandjean Fjord - Bessel Fjord region $\left(75^{\circ}-76^{\circ} \mathrm{N}\right)$ contains the northernmost occurrences of Caledonian granites in North-East Greenland. Most of them have been emplaced along the margins of a sequence of late Proterozoic sediments, the Eleonore Bay Supergroup, or occur within middle Proterozoic metasediments of the Smallefjord sequence. Most granites are undeformed, but granite sheets within the Smallefjord sequence may be foliated. Zircon U-Pb dates indicate that they were emplaced about $400 \mathrm{Ma}$ ago. Sm-Nd, Rb-Sr, and major and trace element analyses suggest that the granites are of mixed origin. Components of crustal origin and juvenile mantle-derived material are present, and occur in variable proportions. Under these circumstances precise dating of the rocks is difficult: $\mathrm{Rb}$-Sr whole-rock errorchrons yield erroneous 'ages' and zircon U-Pb data are not always easily interpreted.
\end{abstract}

B. T. H., Institut für Mineralogie, Westfälische Wilhelms-Universität, Corrensstrasse 24, D-4400 Münster, Germany. Present address: Institut für Geologie und Dynamik der Lithosphäre, University of Göttingen, Goldschmidtsstrasse 3, D-3400 Göttingen, Germany.

N. H. \& F. K., Geological Survey of Greenland, Øster Voldgade 10, DK-1350 Copenhagen $K$, Denmark.

Late- to post-kinematic Caledonian granitic intrusions are common in the southern part of the East Greenland Caledonian fold belt south of $74^{\circ} \mathrm{N}$ (Henriksen, 1985), and occur also in the Grandjean Fjord - Bessel Fjord region between latitudes $75^{\circ}$ and $76^{\circ} \mathrm{N}$ discussed here (Fig. 1). Further north the only late- or post-Caledonian intrusive rocks are pegmatites. Many large intrusions were emplaced in the boundary zone between sediments of the late Proterozoic Eleonore Bay Supergroup and adjacent metamorphic complexes. Caledonian intrusions are also found in the crystalline basement complexes of metasediments and gneisses which occur structurally below the Eleonore Bay Supergroup; they can usually be distinguished from older, pre-Caledonian, granitic rocks by their lack of deformation and foliation. Occasionally, however, early Caledonian intrusions have also suffered deformation and, where emplaced in crystalline complexes, it may be impossible to distinguish them from older granitoid rocks without the help of isotopic age determinations.

$\mathrm{Rb}-\mathrm{Sr}$ whole rock data and zircon $\mathrm{U}-\mathrm{Pb}$ analyses on Caledonian intrusions from the central and southern parts of the East Greenland Caledonian fold belt have yielded ages between 560 and $360 \mathrm{Ma}$ (Hansen \& Steiger, 1976; Hansen \& Tembusch, 1979; Hansen \& Friderichsen,
1987; Hansen et al., 1987; Rex \& Gledhill, 1981; Steiger et al., 1979). However, 'ages' above $480 \mathrm{Ma}$ are derived from poorly constrained $\mathrm{Rb}$-Sr errorchrons, and probably do not date the intrusion of the granites. More reliable ages fall in the range of $c$. $475 \mathrm{Ma}$ for an early plutonic phase to $360 \mathrm{Ma}$ for late granites and veins.

Most of the Caledonian intrusions are large stocks or sheets of homogeneous to porphyritic biotite-muscovite granite. In the Scoresby Sund region $\left(70^{\circ}-72^{\circ} \mathrm{N}\right)$, where plutonic activity has been most intense, the intrusions were emplaced at a more deep-seated level and include also granodioritic, monzonitic and quartz monzonitic types.

This article discusses the age and origin of the northernmost group of Caledonian granites, found in the Grandjean Fjord - Bessel Fjord region $\left(75^{\circ}-76^{\circ} \mathrm{N}\right)$.

\section{Geological setting}

Within the Grandjean Fjord - Bessel Fjord region four main rock units are present (Fig. 1): (1) early Proterozoic basement gneisses and granites which have given isotopic ages of $c$. 2000-1750 Ma (Friderichsen et al., 1994; Kalsbeek et al., 1993); (2) a middle Proterozoic metasedimentary sequence, the Smallefjord sequence, which suf- 


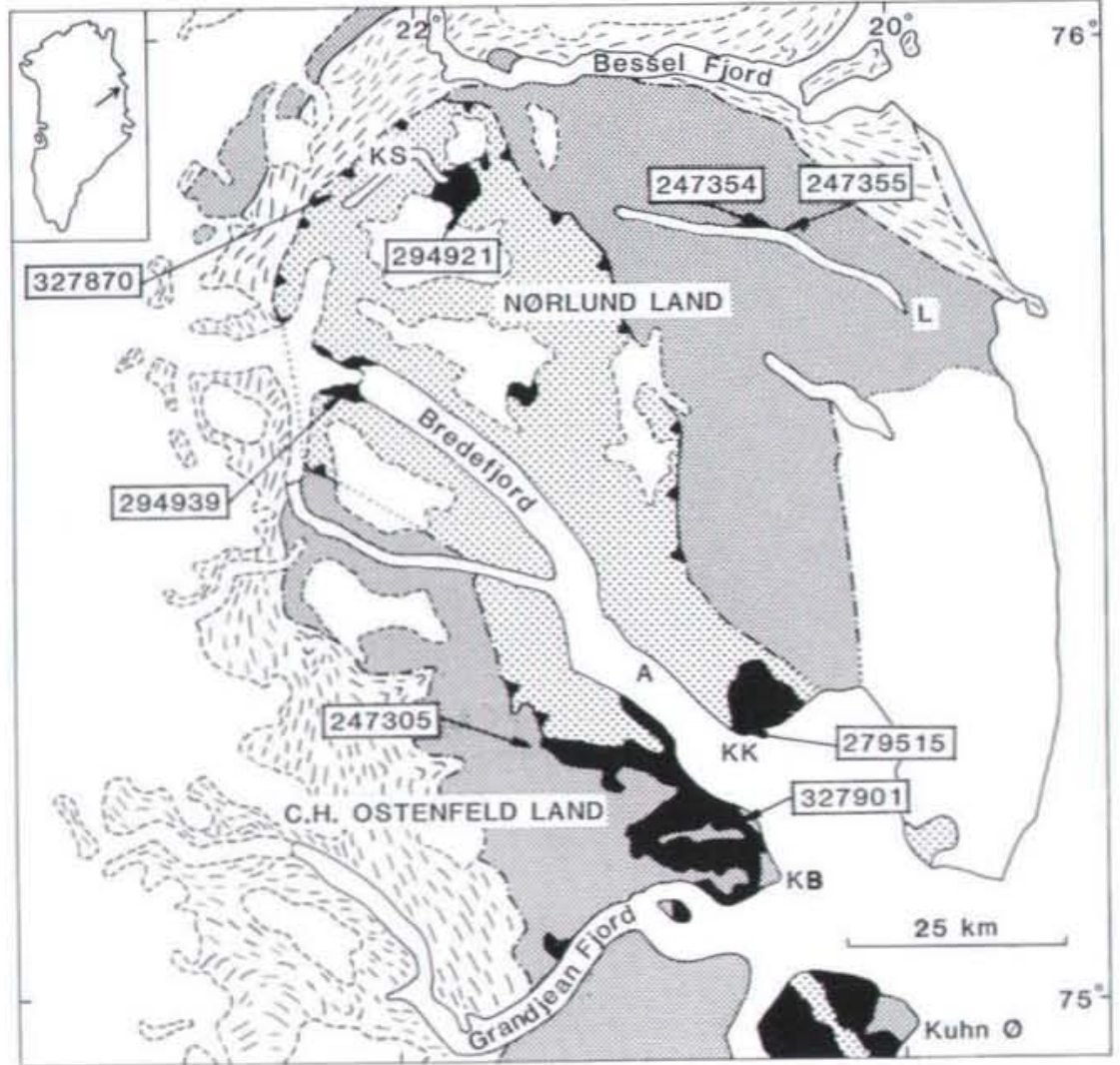

Caledonian granites

$z=$ Basement gneiss complex

Eleonore Bay Supergroup

Smallefjord sequence and other metasediments
Fig. 1. Geological sketch map of the Grandjean Fjord - Bessel Fjord region with the location of the Caledonian granites studied. Numbers correspond to samples analysed and described in text. A: Ardencaple Fjord. KS: Knaksø. KK: Kap Klinkerfues, KB: Kap Buch, L: Langsø.

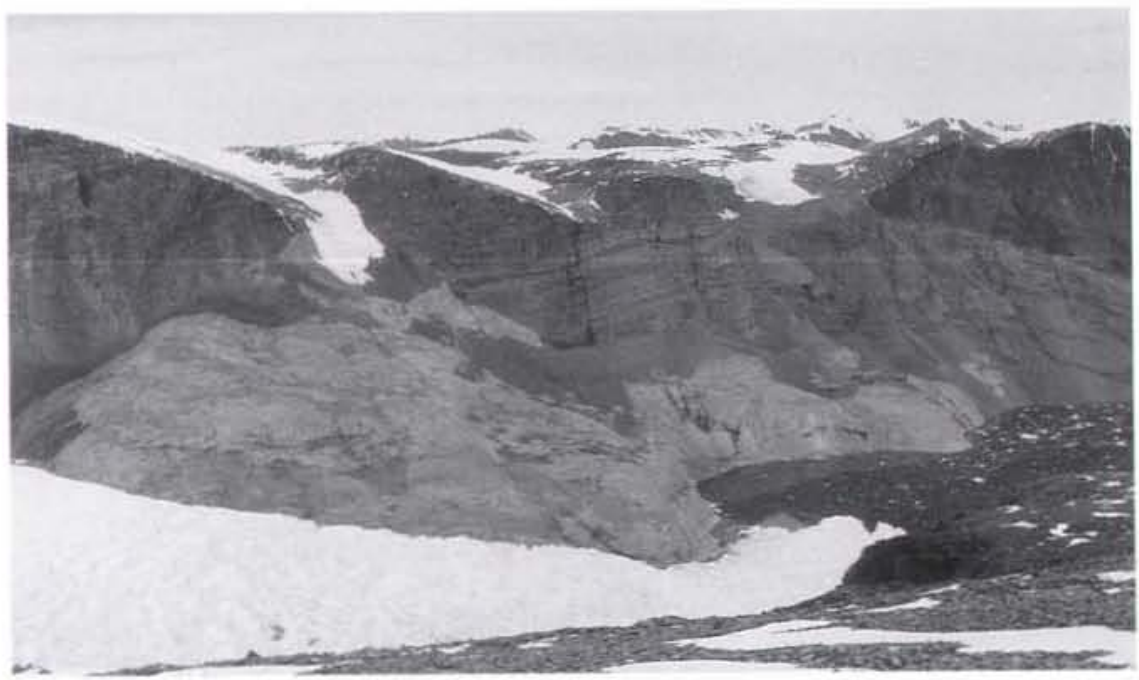

Fig. 2, Caledonian granite discordantly cutting gently folded Eleonore Bay Supergroup sediments at the head of Bredefjord. The mountain at the left is $1300 \mathrm{~m}$ high. Photo: A. K. Higgins. 
fered high-grade migmatisation and metamorphism about 950 Ma ago (Strachan et al., in press); (3) the late Proterozoic Eleonore Bay Supergroup (Sønderholm \& Tirsgaard, 1993), a thick sedimentary sequence occupying a graben-like depression, which exhibits Caledonian deformation and metamorphism, locally reaching amphibolite facies; (4) Caledonian intrusions, mainly leucocratic granites emplaced into sediments of the Eleonore Bay Supergroup and the adjacent middle Proterozoic Smallefjord sequence.

\section{Caledonian granites}

The light coloured granitic intrusions which cut the Eleonore Bay Supergroup in the Grandjean Fjord - Bessel Fjord region were described by Haller (1971) as late orogenic diapiric granites, emplaced as stocks and batholiths. The largest body is a heterogeneous complex south of the mouth of Ardencaple Fjord west of Kap Buch. It cuts both the Eleonore Bay Supergroup and the Smallefjord sequence. Major stock-like bodies are found at Kap Klinkerfues, at the head of Bredefjord (Fig. 2), and at the east side of Knæks $\varnothing$; a few smaller stocks and veins occur elsewhere in Nørlund Land. The Kap Klinkerfues and Bredefjord granites both post-date Caledonian deformation. Northern Kuhn $\varnothing$ is mainly formed by a variety of granites which contain inclusions of supracrustal rocks. The Eleonore Bay Supergroup is here in fault contact with the granites, which cut the Smallefjord sequence further east. The larger granite plutons have dimensions of up to 5-10 km across, while the major irregular body west of Kap Buch can be traced for over $25 \mathrm{~km}$.

The granites cutting the Eleonore Bay sequence and probably also that on Kuhn $\varnothing$, appear to be high level intrusions. They have sharp intrusive contacts, with occasional offshoots and apophyses extending into the country rocks. Locally the intrusions contain raft-like inclusions of sedimentary rocks, especially in their outer parts.

The large granite body west of Kap Buch is rather heterogeneous, in places almost migmatitic; it varies in form from concordant sheets to cross-cutting offshoots. Large inclusions of conformable gneissic schists found as lenses or bands appear to show little relative displacement. The Kap Buch granite was probably emplaced in a series of phases as it shows both deformed and completely homogeneous units.

The Smallefjord sequence, in thrust contact with the younger Eleonore Bay Supergroup, contains a variety of foliated, gneissic granitic sheets, which are generally concordant to slightly discordant to the foliation. During field work these were regarded as older than the essentially undeformed granite intrusions cutting the Eleonore
Table 1. Chemical compositions of Caledonian granites, North-East Greenland

\begin{tabular}{|c|c|c|c|c|c|c|}
\hline GGU No & 247305 & 247354 & 279515 & 294939 & 327870 & 327901 \\
\hline $\mathrm{SiO}_{2}$ & 71.80 & 57.99 & 69.12 & 72.37 & 67.02 & 71.67 \\
\hline $\mathrm{TiO}_{2}$ & 0.26 & 0.74 & 0.49 & 0.27 & 0.63 & 0.22 \\
\hline $\mathrm{Al}_{2} \mathrm{O}_{3}$ & 14.90 & 18.31 & 15.01 & 15.08 & 15.11 & 15.26 \\
\hline $\mathrm{Fe}_{2} \mathrm{O}_{3}$ & 0.02 & 0.55 & 0.11 & 0.08 & 0.44 & 0.00 \\
\hline $\mathrm{FeO}$ & 1.40 & 3.46 & 1.95 & 1.09 & 3.38 & 1.17 \\
\hline $\mathrm{MnO}$ & 0.02 & 0.05 & 0.04 & 0.02 & 0.07 & 0.02 \\
\hline $\mathrm{MgO}$ & 0.67 & 2.12 & 0.90 & 0.45 & 1.93 & 0.50 \\
\hline $\mathrm{CaO}$ & 1.15 & 2.39 & 2.08 & 1.16 & 2.82 & 1.45 \\
\hline $\mathrm{Na}_{2} \mathrm{O}$ & 3.58 & 2.79 & 3.69 & 3.83 & 2.75 & 3.76 \\
\hline $\mathrm{K}_{2} \mathrm{O}$ & 5.10 & 9.01 & 4.48 & 4.88 & 4.24 & 5.04 \\
\hline $\mathrm{P}_{2} \mathrm{O}_{5}$ & 0.15 & 0.36 & 0.19 & 0.12 & 0.18 & 0.12 \\
\hline \multirow[t]{2}{*}{ Volat. } & 0.68 & 1.00 & 1.22 & 0.58 & 1.05 & 0.40 \\
\hline & 99.73 & 98.76 & 99.28 & 99.93 & 99.62 & 99.61 \\
\hline $\mathrm{Rb}$ & 259 & 162 & 174 & 273 & 160 & 203 \\
\hline $\mathrm{Ba}$ & 337 & 4810 & 993 & 542 & 1930 & 551 \\
\hline $\mathrm{Pb}$ & 42 & 94 & 38 & 36 & 35 & 39 \\
\hline $\mathrm{Sr}$ & 113 & 1226 & 687 & 250 & 1966 & 165 \\
\hline Y & 13 & 18 & 14 & 15 & 28 & 12 \\
\hline Th & 12 & 51 & 18 & 15 & 26 & 11 \\
\hline $\mathrm{Zr}$ & 103 & 841 & 197 & 144 & 153 & 124 \\
\hline $\mathrm{Nb}$ & 5.8 & 6.1 & 9.6 & 6.0 & 9.8 & 9.6 \\
\hline $\mathrm{Ni}$ & 5 & 21 & 5 & 4 & 20 & 3 \\
\hline V & 17 & 39 & 27 & 10 & 70 & 8 \\
\hline $\mathrm{Cr}$ & 14 & 48 & 9 & 5 & 46 & 5 \\
\hline Ga & 25 & 19 & 21 & 21 & 22 & 21 \\
\hline $\mathrm{K}_{2} \mathrm{O} / \mathrm{Na}_{2} \mathrm{O}$ & 1.42 & 3.23 & 1.22 & 1.27 & 1.54 & 1.34 \\
\hline $\mathrm{K} / \mathrm{Rb}$ & 167 & 456 & 213 & 149 & 224 & 205 \\
\hline $\begin{array}{l}\mathrm{Rb} / \mathrm{Zr} \\
\mathrm{Al}_{2} \mathrm{O}_{3} / \mathrm{Na}_{2} \mathrm{O}\end{array}$ & 2.47 & 0.20 & 0.89 & 1.88 & 1.03 & 1.65 \\
\hline $\begin{array}{l}\mathrm{Al}_{2} \mathrm{O}_{3} / \mathrm{Na}_{2} \mathrm{O} \\
+\mathrm{K}_{2} \mathrm{O}+\mathrm{CaO}\end{array}$ & 1.20 & 1.11 & 1.17 & 1.19 & 1.29 & 1.18 \\
\hline
\end{tabular}

Major elements analysed at the Geological Survey of Greenland mostly by XRF on glass discs, $\mathrm{Na}_{2} \mathrm{O}$ by $\mathrm{AAS}, \mathrm{FeO} / \mathrm{Fe}_{2} \mathrm{O}_{3}$ by titration. Trace elements determined by XRF on powder tablets at the Department of Geology, University of Copenhagen. Description of samples in Appendix 1.

Bay Supergroup. However, two of these sheets have been dated, and also give Caledonian ages.

The intrusive bodies in the Smallefjord sequence usually form anastomosing complexes which may form 'bodies' tracable over several kilometres. Some are folded (Friderichsen et al., 1994) and may exhibit foliation and lineation. At Langs $\emptyset$, early foliated granite sheets are cut by several generations of later unfoliated granite sheets; their formation clearly spans over an extended period of time.

The majority of Caledonian granites are leucocratic, fine to medium grained, with quartz, microcline, plagioclase, biotite and muscovite as main minerals. Occasionally the rocks are granodioritic and one of the investi- 

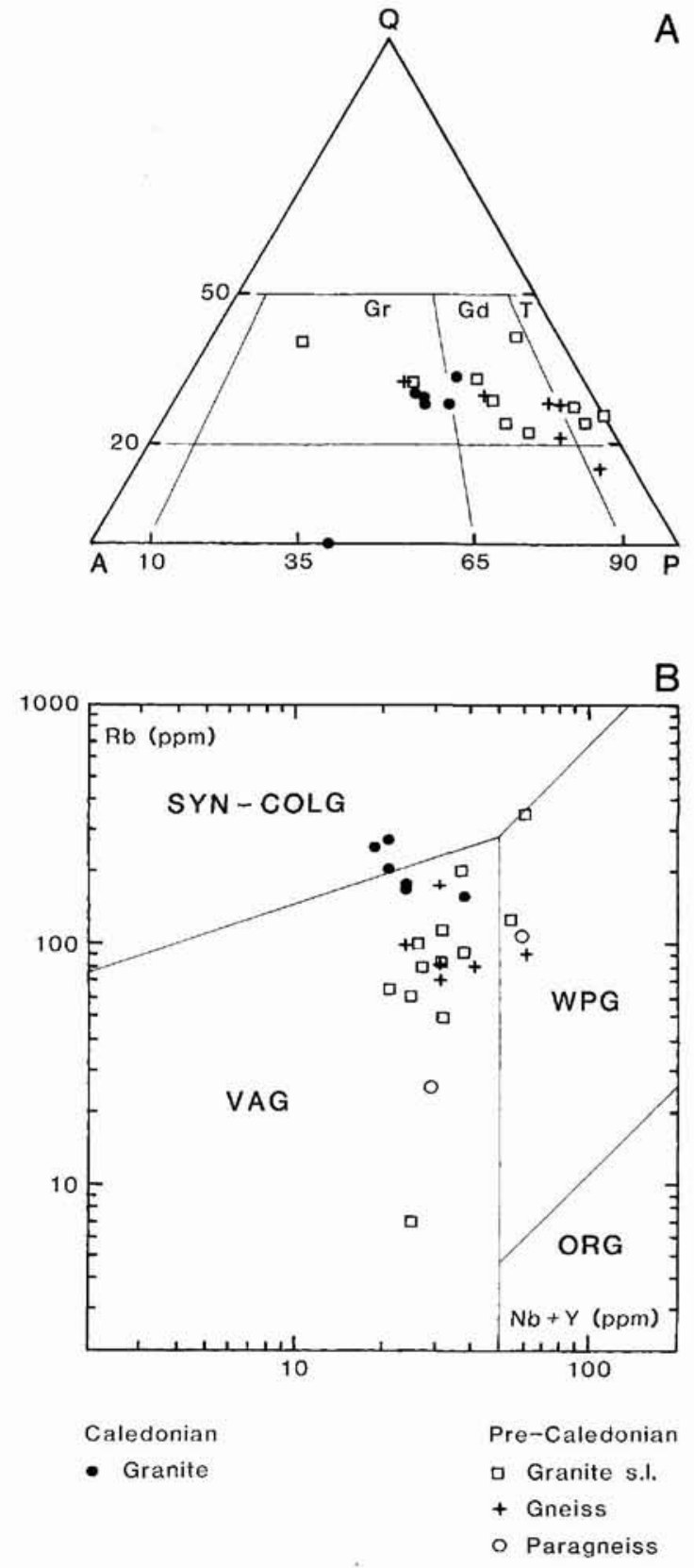

Fig. 3. A: Quartz-alkali feldspar-plagioclase (QAP) diagram according to Streckeisen (1976). Proportions of Q, A and P were calculated from the chemical analyses, normative hypersthene and $\mathrm{K}$-feldspar being recalculated into equivalent proportions of biotite and quartz. Pre-Caledonian basement rocks are granitic to tonalitic, $(\mathrm{Gr}=$ granite $; \mathrm{Gd}=$ granodiorite $; \mathrm{T}=$ tonalite $)$, whereas the Caledonian intrusives are granite to granodiorite, with one syenitic sample. B: Diagram discriminating between granitoid rocks of different tectonic settings according to Pearce et al. (1984). VAG: volcanic arc granites, SYN-COLG: syncollision granites, WPG: within-plate granites, ORG: ocean ridge granites. gated samples is of syenitic composition. Porphyritic types contain feldspars up to a few centimetres in size. Some rocks show slight alteration with chloritisation of biotite and saussuritisation of the plagioclase.

Six samples of Caledonian intrusive bodies have been chemically analysed (Table 1); some chemical data are illustrated in Figure 3 in which the compositions of the surrounding pre-Caledonian rocks are also shown for comparison. The Q-A-P (quartz, alkali feldspar, plagioclase) diagram according to Streckeisen (1976) shows that the analysed samples straddle the border between granites and granodioritic rocks, while one is a syenite (Fig. 3A). The Caledonian granites are clearly more potassic than most of the pre-Caledonian basement rocks. The granites are also more $\mathrm{Rb}$-rich than samples from the basement. In the diagram of Pearce et al. (1984) to discriminate between granites from different geological settings they fall in or near the field of 'syn-collision granites' (Fig. 3B). The granites are peraluminous (molecular $\mathrm{Al}_{3} \mathrm{O}_{3}>\mathrm{Na}_{2} \mathrm{O}+\mathrm{K}_{2} \mathrm{O}+\mathrm{CaO}$ ) and have high $\mathrm{K} / \mathrm{Na}$ ratios (Table 1).

\section{Zircon U-Pb data}

$\mathrm{U}-\mathrm{Pb}$ data have been obtained from zircon concentrates from six Caledonian granite intrusions. A brief description of the samples and their field setting is given in Appendix 1. The analytical work (Table 2) was carried out at the Zentrallaboratorium für Geochronologie (ZLG) at the University of Münster, Germany. The analytical procedure and constants used for calculation are summarised in Appendix 2.

In the ${ }^{206} \mathrm{~Pb} /{ }^{238} \mathrm{U}-{ }^{207} \mathrm{~Pb} /{ }^{235} \mathrm{U}$ diagram most isotope ratios plot rather close to the concordia between 400 and $450 \mathrm{Ma}$. Unfortunately different zircon size fractions from the various samples show only very limited spread in isotope ratios, and it is therefore difficult to fit reliable discordia lines through the data points. Interpretation of the data in terms of precise ages is therefore not always straightforward. In Table 3 we list the intersections of best-fit discordia lines with the concordia. Sm-Nd and $\mathrm{Rb}-\mathrm{Sr}$ data, described later in this paper, indicate that the Caledonian granites in question contain significant proportions of early Proterozoic or older crustal material, and it is likely that the analysed zircon concentrates also contain small proportions of zircon derived from such earlier granitoid rocks. Accordingly, regression calculations have also been carried out with a fixed upper intercept with the concordia at $1800 \mathrm{Ma}$ (Table 3). Since most analysed zircon fractions lie close to the lower intercept, these regression lines essentially represent 'two point isochrons' without geological significance; how- 
Table 2. Zircon $\mathrm{U}-\mathrm{Pb}$ isotope data for Caledonian granites, North-East Greenland

\begin{tabular}{|c|c|c|c|c|c|c|c|c|c|c|c|c|c|}
\hline \multicolumn{2}{|c|}{$\begin{array}{l}\text { Sample/ } \\
\text { fraction } \\
\mu \mathrm{m}\end{array}$} & $\begin{array}{c}\mathrm{U} \\
(\mathrm{ppm})\end{array}$ & $\begin{array}{c}\mathrm{Pb} \\
\text { (ppm) } \\
\text { total }\end{array}$ & $\begin{array}{c}\mathrm{Pb}^{*} \\
(\mathrm{ppm}) \\
\mathrm{rad}\end{array}$ & $\begin{array}{l}{ }^{206} \mathrm{~Pb} / \\
{ }^{204} \mathrm{~Pb}\end{array}$ & $\begin{array}{c}{ }^{207} \mathrm{~Pb} / \\
\text { Measured } \mathrm{r}\end{array}$ & $\begin{array}{l}{ }_{{ }^{208} \mathrm{~Pb} /} \\
{ }^{206} \mathrm{~Pb}\end{array}$ & $\begin{array}{r}{ }^{206} \mathrm{~Pb} / \\
{ }^{238} \mathrm{U}\end{array}$ & $\begin{array}{c}{ }_{{ }^{207} \mathrm{~Pb} /}{ }^{235} \mathrm{U} \\
\text { culated rat }\end{array}$ & ${ }^{{ }^{206} \mathrm{~Pb} /}$ & $\begin{array}{l}{ }^{206} \mathrm{~Pb} / \\
{ }^{236} \mathrm{U} \\
\text { Appare }\end{array}$ & $\begin{array}{c}{ }^{207} \mathrm{~Pb} / \\
{ }^{235} \mathrm{U} \\
\text { ent ages }\end{array}$ & $\begin{array}{r}{ }^{207} \mathrm{~Pb} / \\
{ }^{206} \mathrm{~Pb} \\
\text { in } \mathrm{Ma}\end{array}$ \\
\hline \multicolumn{14}{|c|}{ GGU No 247305} \\
\hline a) & $40-60$ & 3984 & 379.0 & 325.5 & 323.9 & 0.100936 & 0.479512 & 0.065859 & 0.50766 & 0.055906 & 411.2 & 416.9 & 448.6 \\
\hline b) & $60-80$ & 3656 & 306.2 & 253.0 & 303.2 & 0.104831 & 0.270914 & 0.066367 & 0.51963 & 0.056786 & 414.2 & 424.9 & 483.2 \\
\hline c) & $80-100$ & 4060 & 358.2 & 292.4 & 273.8 & 0.110670 & 0.325774 & 0.066506 & 0.52730 & 0.057503 & 415.1 & 430.0 & 510.9 \\
\hline \multicolumn{14}{|c|}{ GGU No 247354} \\
\hline d) & $<40$ & 493 & 38.5 & 34.2 & 477.8 & 0.086630 & 0.238259 & 0.065958 & 0.51036 & 0.056119 & 411.8 & 418.7 & 457.0 \\
\hline e) & $40-60$ & 558 & 42.9 & 38.2 & 497.5 & 0.085665 & 0.224779 & 0.065588 & 0.50976 & 0.056368 & 409.5 & 418.3 & 466.9 \\
\hline f) & $60-80$ & 870 & 66.5 & 56.4 & 363.3 & 0.096244 & 0.211595 & 0.064418 & 0.49844 & 0.056118 & 402.4 & 410.7 & 457.0 \\
\hline \multicolumn{14}{|c|}{ GGU No 247355} \\
\hline g) & $<100$ & 1655 & 110.2 & 106.5 & 1867.4 & 0.066492 & 0.055826 & 0.068405 & 0.55374 & 0.058711 & 426.5 & 447.4 & 556.4 \\
\hline \multicolumn{14}{|c|}{ GGU No 279515} \\
\hline h) & $<40$ & 1264 & 88.1 & 86.7 & 3461.6 & 0.060473 & 0.151149 & 0.066564 & 0.51637 & 0.056263 & 415.4 & 422.7 & 462.7 \\
\hline i) & $40-60$ & , 1441 & 101.8 & 100.0 & 3022.1 & 0.062231 & 0.138365 & 0.068148 & 0.53950 & 0.057416 & 425.0 & 438.1 & 507.5 \\
\hline j) & $60-80$ & 1443 & 113.0 & 111.2 & 3400.2 & 0.063707 & 0.127697 & 0.076092 & 0.62360 & 0.059438 & 472.8 & 492.1 & 583.1 \\
\hline k) & $80-100$ & 1426 & 108.4 & 106.0 & 2655.3 & 0.067570 & 0.111837 & 0.074543 & 0.63848 & 0.062122 & 463.5 & 501.4 & 678.3 \\
\hline \multicolumn{14}{|c|}{ GGU No 294921} \\
\hline 1) & $40-60$ & 4601 & 554.2 & 297.1 & 90.2 & 0.218594 & 0.507197 & 0.064363 & 0.50645 & 0.057070 & 402.1 & 416.1 & 494.2 \\
\hline m) & $60-80$ & 2828 & 254.3 & 182.2 & 179.5 & 0.139336 & 0.296140 & 0.065181 & 0.52426 & 0.058334 & 407.1 & 428.0 & 542.3 \\
\hline n) & $80-100$ & 2859 & 250.5 & 184.2 & 194.1 & 0.132831 & 0.277173 & 0.065228 & 0.52046 & 0.057870 & 407.3 & 425.5 & 524.8 \\
\hline \multicolumn{14}{|c|}{ GGU No 294939} \\
\hline o) & $80-100$ & 3155 & 296.8 & 230.8 & 233.6 & 0.123354 & 0.268941 & 0.072247 & 0.60674 & 0.060909 & 449.5 & 484.1 & 651.4 \\
\hline p) & $100-125$ & 3920 & 398.5 & 255.8 & 138.1 & 0.162262 & 0.298363 & 0.069962 & 0.54837 & 0.056847 & 436.0 & 443.7 & 483.8 \\
\hline
\end{tabular}

Analysed at the Zentrallaboratorium für Geochronologie (ZLG) at the University of Münster, Germany. For analytical methods, precisions etc. see Appendix 2. Table 3 gives the results of various regression calculations.

ever, their lower interceptions may in some cases be close to the time of emplacement of the granites.

GGU 247305, Femdalen. The sample represents a foliated granite emplaced into metasediments of the Smallefjord sequence (Fig. 1). The zircons in the three analysed fractions are uniform in appearance. The crystals are clear to slightly brown, euhedral, long-prismatic, and have an average length-width ratio of $c .3$, increasing with increasing grain size. Inclusions are very rare, as are signs of multiple growth around older cores. The lower discordia intercept at $409_{-8}^{+4} \mathrm{Ma}$ (MSWD 0.27) in Figure $4 \mathrm{a}$ is therefore interpreted as the time of emplacement of the granite. A discordia with an upper intercept at 1800 Ma gives an age of $402+4 \mathrm{Ma}$ (MSWD 1.20), within error the same as the best-fit discordia line. Muscovite from an undeformed granite sheet in the same area gave an ${ }^{40} \mathrm{Ar} /{ }^{39} \mathrm{Ar}$ plateau age of $402 \mathrm{Ma}$ (Dallmeyer et al., 1994; Dallmeyer \& Strachan, 1994).

GGU 247354, Langsø. This sample originates from a granitoid gneiss of syenitic composition (chemical analy- sis in Table 1) intruding metasediments of the Smallefjord sequence (Fig. 1). Zircons from this sample are mainly brownish, partly translucent, elongated grains with a length-width ratio between 2 and 3 . Nearly all crystals show rounded terminations; a few have idiomorphic habits. Even in the fraction $<40 \mu \mathrm{m}$ more than $90 \%$ of the grains are rounded and crystal faces can only rarely be recognised. A best-fit discordia line through the three fractions analysed yields an upper intercept at $473_{-49}^{+50} \mathrm{Ma}$ (MSWD 0.35) and, within limits of error, passes through the origin (Fig. 4b).

It is possible that the $473 \mathrm{Ma}$ date is the age of emplacement of the syenite. However, Sm-Nd data suggest that the sample comprises a mixture of new mantlederived and older crustal material. If the rock contains remnants of older zircons, the $473 \mathrm{Ma}$ age would be too high. Alternatively, the data could be interpreted in terms of a reversed discordia model; the age obtained would then be an upper limit for the emplacement. Assuming an inherited component with an age of some $1800 \mathrm{Ma}$ the 
calculated discordia would have a lower intercept at 400 Ma (MSWD 4.45, Table 3), which might be close to the time of intrusion. It is not clear which interpretation is to be preferred.

GGU 247355, Langsø. This sample is from an aplite sheet within the Smallefjord sequence (Fig. 1). Only a total zircon fraction $<100 \mu \mathrm{m}$ could be separated, and is composed of a mixture of broken crystals of prismatic habit, ranging in colour from translucent to rose to light brown. A discordia line with an upper intercept at 1800 Ma through the data point for this sample yields a lower intercept at c. $400 \mathrm{Ma}$, identical to that for GGU 247354 (Fig. 4b). A discordia drawn through $1800 \mathrm{Ma}$ and all data points for both samples 247354 and 247355 gives a lower intercept at $396_{-9}^{+6} \mathrm{Ma}$ (Fig. 4b). An ${ }^{40} \mathrm{Ar} /{ }^{39} \mathrm{Ar}$ plateau age on muscovite from a similar aplite in the same setting gave an age of $385 \mathrm{Ma}$ (Dallmeyer et al., 1994; Dallmeyer \& Strachan, 1994).

GGU 279515, Kap Klinkerfues. This sample is from an undeformed granite intruded into the Eleonore Bay Supergroup. The four zircon fractions analysed all show rounded terminations, and have a length-width ratio of 2-3 which decreases with increasing grain size. The colours vary strongly. The finest fraction is composed of clear, light rose crystals, the two intermediate fractions contain an increasing proportion of turbid rose coloured zircons, whereas the coarsest fraction is đominated by rounded crystals of brownish colour. Three of the four fractions (h, i, k, Fig. 4c) define a discordia with a lower intercept corresponding to an age of $405_{-2}^{+2} \mathrm{Ma}$ (MSWD $0.38)$. This age is slightly lowered $\left(385_{-15}^{+10} \mathrm{Ma}\right)$ if the fraction $\mathrm{j}$ (Fig. 4c) is used in the regression instead of fraction $\mathrm{k}$; however, the MSWD value then goes up to 27.5 (Table 3 ). From an analytical point of view there is no reason to give preference to point $\mathrm{k}$, except for the MSWD value of the regression. Whichever point is used, the age for the emplacement of the granite at about 400 $\mathrm{Ma}$ is not changed significantly. Even a discordia drawn with an upper intercept of $1800 \mathrm{Ma}$ for the different combinations gives an intercept at c. $410 \mathrm{Ma}$ (Table 3). The most probable interpretation is that the zircons are a mixture of old (coarser) zircons and new grown crystals formed during emplacement of the granite at about 400 Ma.

GGU 294921, east of Knæksø. Sample taken from an undeformed porphyritic granite emplaced into sediments of the Eleonore Bay Supergroup (Fig. 1). The zircons from three analysed fractions show no difference in morphology. All crystals are brownish and elongated with slightly rounded terminations. The length-width ratio increases from 2 to 4 with decreasing grain size. All fractions are free of inclusions; a few colourless, translucent crystals are found in the finest fraction. The homogeneity
Table 3. Intersections of discordia lines for zircon $\mathrm{U}-\mathrm{Pb}$ data

\begin{tabular}{lcccccc}
\hline GGU No & $\begin{array}{c}\text { Lower } \\
\text { intercept Ma }\end{array}$ & $\begin{array}{c}\text { Upper } \\
\text { intercept Ma }\end{array}$ & MSWD & $\begin{array}{l}\text { Points used } \\
\text { for regress. }\end{array}$ \\
\hline A & & & & & & \\
247305 & 409 & $+4 /-8$ & 2710 & $+2038 /-990$ & 0.27 & a, b, c \\
247354 & 87 & $+319 /-1688$ & 473 & $+50 /-49$ & 0.36 & d, e, f \\
247355 & 396 & $+6 /-9$ & 1562 & $+230 /-210$ & 3.01 & d, e, f, g \\
279515 & 405 & $+2 /-2$ & 1588 & $+47 /-46$ & 0.38 & h, i, k \\
279515 & 385 & $+10 /-15$ & 967 & $+123 /-115$ & 27.54 & h, i, j \\
294921 & - & - & - & - & - & l. m, n \\
294939 & 432 & $+9 /-14$ & 2677 & $+1060 /-694$ & - & o, p \\
& & & & & & \\
$B$ & 402 & $+4 /-4$ & & 1800 & 1.20 & a, b, c \\
247305 & 400 & $+2 /-2$ & & 1800 & 4.45 & d, c, f \\
247354 & 400 & $+2 /-2$ & & 1800 & 3.65 & d, e, f, g \\
247355 & 412 & $+4 /-4$ & & 1800 & 33.63 & h, i, k \\
279515 & 413 & $+11 /-11$ & & 1800 & 1.80 & h, i, j \\
279515 & 382 & $+7 /-7$ & & 1800 & 0.19 & l, m, n \\
294921 & 412 & $+7 /-7$ & & 1800 & 3.61 & o, p \\
294939 & & & & & &
\end{tabular}

A: best-fit discordia.

B: discordia with fixed upper intersection at $1800 \mathrm{Ma}$

of the zircons is also reflected in the isotopic ratios obtained (Fig. 4d), which are so close to each other that no reliable discordia can be calculated. A discordia drawn with an upper intercept at $1800 \mathrm{Ma}$ through the cluster of data points yields a lower intercept at $382 \mathrm{Ma}$. This age is significantly lower than an ${ }^{40} \mathrm{Ar} /{ }^{39} \mathrm{Ar}$ plateau age of 423 $\mathrm{Ma}$ obtained on muscovite from this granite, interpreted as dating post-magmatic cooling of the intrusion (Dallmeyer et al., 1994; Dallmeyer \& Strachan, 1994). The zircon age cannot, therefore, date the emplacement of the granite; the discrepancy may be due to sub-recent $\mathrm{Pb}$ loss from the zircons.

$G G U$ 294939, head of Bredefjord. This large granite stock at the head of Bredefjord (Figs 1,2) is undeformed and appears to post-date a Caledonian anticline in sediments of the Eleonore Bay Supergroup. The two zircon size fractions analysed are of similar appearance. All grains are stubby with frequent dark inclusions and brownish to clear in colour; their surfaces are corroded and their terminations partly rounded. A best fit discordia intersects the concordia at $432_{-14}^{+9} \mathrm{Ma}$ (Fig. 4e). A discordia line drawn through the data points with an upper intercept at $1800 \mathrm{Ma}$ yields a lower intersection at $412_{-7}^{+7}$ $\mathrm{Ma}$ (Table 3). Unless recent $\mathrm{Pb}$ loss has taken place, these ages must be close to the time of emplacement of the granite. Muscovite from the Bredefjord granite has yielded an ${ }^{40} \mathrm{Ar}{ }^{39} \mathrm{Ar}$ plateau age of $411 \mathrm{Ma}$ (Dallmeyer $e t$ al., 1994; Dallmeyer \& Strachan, 1994).

\section{Sm-Nd isotope data}

Sm-Nd isotope data (Table 4) were acquired for six samples of different Caledonian granites, for which 

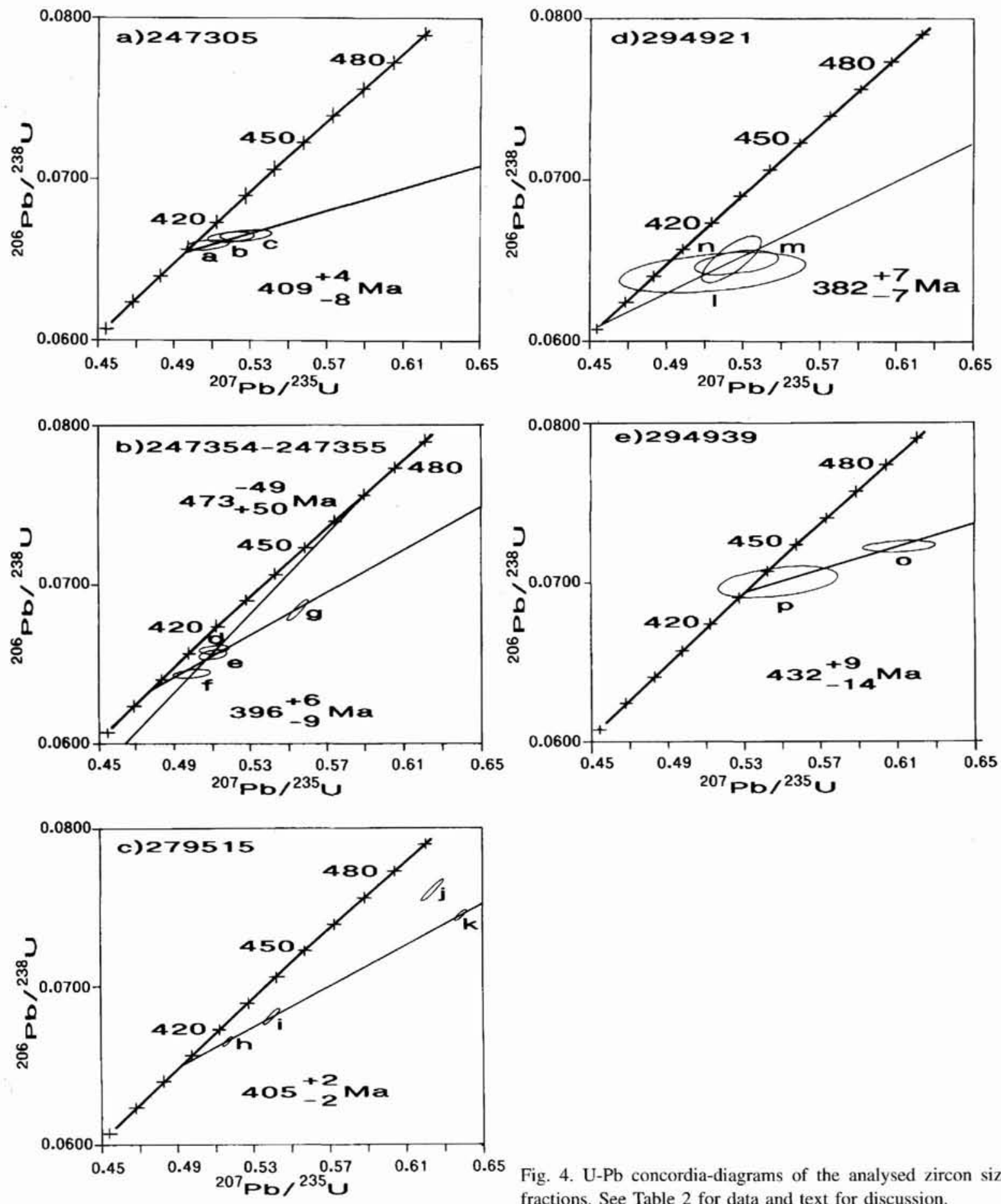

Fig. 4. U-Pb concordia-diagrams of the analysed zircon size fractions. See Table 2 for data and text for discussion.

chemical data are also available. Locations and brief descriptions of the intrusions, all in the Grandjean Fjord Bessel Fjord area, are given in Appendix 1.

Model ages, calculated according to the depleted mantle model of DePaolo (1981), range from 1.06 to $1.77 \mathrm{Ga}$.
Obviously, these ages have no chronological significance with respect to the age of emplacement of the granites, which on grounds of cross-cutting relationships with the Eleonore Bay Supergroup and/or zircon isotope data is known to be Caledonian. 
Table 4. Sm-Nd and Rb-Sr isotope data for six Caledonian granites, North-East Greenland

\begin{tabular}{|c|c|c|c|c|c|c|c|c|c|}
\hline \multirow{2}{*}{$\frac{\text { GGU No }}{247305}$} & $\begin{array}{c}\mathrm{Sm} \\
(\mathrm{ppm})\end{array}$ & \multicolumn{2}{|c|}{$\begin{array}{c}\mathrm{Nd} \\
(\mathrm{ppm})\end{array}$} & \multicolumn{2}{|c|}{$\begin{array}{l}{ }^{147} \mathrm{Sm} / \\
{ }^{144} \mathrm{Nd}\end{array}$} & \multicolumn{2}{|c|}{$\begin{array}{l}{ }^{143} \mathrm{Nd} / \\
{ }_{144} \mathrm{Nd}\end{array}$} & $\mathrm{T}_{\mathrm{DM}}$ & \multirow{2}{*}{$\begin{array}{c}\varepsilon_{\mathrm{Nd}} \\
(0.4 \mathrm{Ga}) \\
-8.1\end{array}$} \\
\hline & 4.946 & \multicolumn{2}{|c|}{23.270} & \multicolumn{2}{|c|}{0.1285} & \multicolumn{2}{|c|}{0.512046} & 1.77 & \\
\hline 247354 & 16.099 & \multicolumn{2}{|c|}{145.937} & \multicolumn{2}{|c|}{0.0667} & \multicolumn{2}{|c|}{0.512017} & 1.06 & -5.5 \\
\hline 279515 & 6.855 & \multicolumn{2}{|c|}{44.892} & \multicolumn{2}{|c|}{0.0923} & \multicolumn{2}{|c|}{0.512102} & 1.18 & -5.1 \\
\hline 294939 & $5-442$ & \multicolumn{2}{|c|}{30.724} & \multicolumn{2}{|c|}{0.1071} & \multicolumn{2}{|c|}{0.512055} & 1.41 & -6.8 \\
\hline 327870 & 10.099 & \multicolumn{2}{|c|}{73.139} & \multicolumn{2}{|c|}{0.0835} & \multicolumn{2}{|c|}{0.512021} & 1.19 & -6.3 \\
\hline 327901 & 4.285 & \multicolumn{2}{|c|}{23.211} & \multicolumn{2}{|c|}{0.1116} & \multicolumn{2}{|c|}{0.512062} & 1.46 & -6.9 \\
\hline GGU No & \multicolumn{2}{|c|}{$\mathrm{Rb}$ (ppm) } & \multicolumn{2}{|c|}{$\mathrm{Sr}(\mathrm{ppm})$} & & & \multicolumn{2}{|c|}{${ }^{87} \mathrm{Sr} /{ }^{86} \mathrm{Sr}$} & $\mathrm{Sr}_{400}$ \\
\hline 247305 & \multicolumn{2}{|c|}{259} & \multicolumn{2}{|c|}{113} & \multicolumn{2}{|c|}{6.652} & \multicolumn{2}{|c|}{0.76694} & 0.729 \\
\hline 247354 & \multicolumn{2}{|c|}{162} & \multicolumn{2}{|c|}{1226} & \multicolumn{2}{|c|}{.382} & \multicolumn{2}{|c|}{0.71822} & 0.716 \\
\hline 279515 & \multicolumn{2}{|c|}{174} & & & & 732 & 0.7 & 97 & 0.710 \\
\hline 294939 & & & & & & 182 & 0.7 & 116 & 0.716 \\
\hline 327870 & & & & & & 235 & & 74 & 0.709 \\
\hline 327901 & & & & & & 577 & 0.7 & 570 & 0.717 \\
\hline
\end{tabular}

Sm-Nd data were acquired at the Age and Isotope Laboratory, Department of Earth Sciences, University of Oxford. Analytical uncertainties are estimated as c. $0.1 \%$ for $\mathrm{Sm}$ and $\mathrm{Nd}$ concentrations, $0.2 \%$ for ${ }^{147} \mathrm{Sm} /{ }^{143} \mathrm{Nd}$, and 0.000010 for ${ }^{143} \mathrm{Sm} /{ }^{144} \mathrm{Nd}$ ( $1 \sigma$ values). $\mathrm{T}_{\mathrm{DM}}$ values are crustal residence model ages calculated according to the depleted mantle model of DePaolo (1981). Rb, $\mathrm{Sr}$ and ${ }^{87} \mathrm{Sr} /{ }^{56} \mathrm{Sr}$ were determined at the XRF laboratory and 'Dansk Center for Isotopgeologi', respectively, both at the Department of Geology, University of Copenhagen. $\mathrm{Rb}$ and $\mathrm{Sr}$ (calibrated against USGS rock standards, matrix correction from major element analyses) \pm c. $2 \% ;{ }^{87} \mathrm{Rb} /{ }^{86} \mathrm{Sr} \pm c .1 \% \cdot{ }^{87} \mathrm{Sr} /{ }^{86} \mathrm{Sr}$ ratios have a precision of $c .0 .005 \%$. During the period of analysis, a mean ${ }^{87} \mathrm{Sr} /{ }^{86} \mathrm{Sr}$ ratio of $0.710262 \pm 16(\mathrm{n}=12)$ was obtained on the NBS987 $\mathrm{Sr}$ standard (accepted value 0.710248 ). $\mathrm{Sr}_{400}$ represents the ${ }^{87} \mathrm{Sr} /{ }^{86} \mathrm{Sr}$ ratio $400 \mathrm{Ma}$ ago.

Figure 5 depicts the range of ${ }^{143} \mathrm{Nd} /{ }^{144} \mathrm{Nd}$ ratios $400 \mathrm{Ma}$ ago, (the approximate age of the granites), compared to $\mathrm{Nd}$ isotope ratios for a 'chondritic' and a 'depleted' mantle, in terms of the $\varepsilon$ notation (see Faure, 1986). $\varepsilon$ values represent deviations from chondritic ${ }^{143} \mathrm{Nd} /{ }^{144} \mathrm{Nd}$ ratios at any time; $400 \mathrm{Ma}$ ago the analysed Caledonian granites had $\varepsilon$ values ranging from $c$. -5 to -8 . At that time a depleted mantle would have had an $\varepsilon$ value of $c$. +7.5 (Fig. 5) and a chondritic mantle $\varepsilon=0$, and it is therefore apparent that the granites in question cannot have formed entirely from sources derived from the mantle $400 \mathrm{Ma}$ ago. A significant proportion of older crustal material with low $\varepsilon$ values must be present in these granites.

Three of the analysed samples have $\mathrm{T}_{\mathrm{DM}}<1.2 \mathrm{Ga}$ (Table 4). These samples are characterised by high concentrations of $\mathrm{Sr}(687,1226$, and $1966 \mathrm{ppm})$, and have respectively 174, 162, and $160 \mathrm{ppm} \mathrm{Rb}$ (Tables 1 and 4). Three other samples have $\mathrm{T}_{\mathrm{DM}}>1.4 \mathrm{Ga}$, much lower $\mathrm{Sr}$ $(113,165$, and $250 \mathrm{ppm})$, and higher $\mathrm{Rb}(259,203$, and $273 \mathrm{ppm}$ ). The latter three samples also have lower ${ }^{147} \mathrm{Sm} /{ }^{144} \mathrm{Nd}$ ratios than the former: $0.07-0.09$ as against $0.11-0.13$.

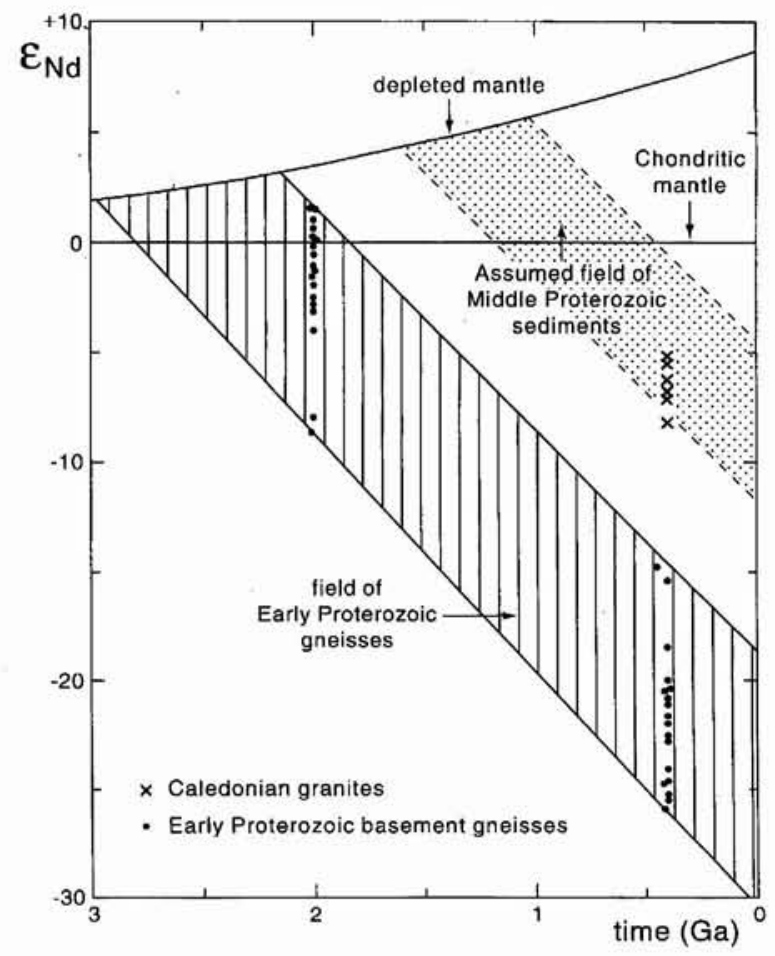

Fig. 5. Sm-Nd evolution diagram comparing the isotopic composition of Caledonian granites with that of early Proterozoic basement gneisses and middle Proterozoic sediments. For explanation see text.

\section{Rb-Sr data}

$\mathrm{Rb}-\mathrm{Sr}$ whole rock isotope data have been acquired for the six granite samples from which we have Sm-Nd data (Table 4), as well as for a number of samples (some outside the Grandjean Fjord - Bessel Fjord area) collected in an attempt to obtain $\mathrm{Rb}-\mathrm{Sr}$ isochron ages (Table 5). The latter sample collections were made at Kap Buch (Fig. 1), at Eskimonæs (aplite granite), and from a Caledonian granite pluton at Ankerbjerg (Fig. 6A). Unlike the granites at Kap Buch and Ankerbjerg, which cut sediments of the Eleonore Bay Supergroup (Fig. 6B), the Eskimonæs aplite granite occurs as sheets within basement gneisses, and a Caledonian age for this intrusion is therefore not certain.

The six Sm-Nd samples had high ${ }^{87} \mathrm{Sr} /{ }^{86} \mathrm{Sr}$ ratios (0.709-0.729) at their time of intrusion, c. $400 \mathrm{Ma}$ ago (Table 4). This confirms evidence from Sm-Nd data that the granites contain significant proportions of older crust. The sample with the highest $\mathrm{T}_{\mathrm{DM}}$ value (GGU 247305, $\mathrm{T}_{\mathrm{DM}} 1.77 \mathrm{Ga}$ ) and with the highest $\mathrm{Rb} / \mathrm{Sr}$ ratio $(6.65)$ also had the highest ${ }^{87} \mathrm{Sr} /{ }^{86} \mathrm{Sr}$ ratio $400 \mathrm{Ma}$ ago (0.729); this compares with $0.709-0.717$ for the other samples.

None of the other sample collections yielded reliable 
isochrons (Fig. 6B, C). Seven of the eight samples analysed from the Ankerbjerg pluton fall along an errorchron, age $542 \pm 32 \mathrm{Ma}$, initial ${ }^{87} \mathrm{Sr} /{ }^{86} \mathrm{Sr}$ ratio $\left(\mathrm{Sr}_{\mathrm{i}}\right) 0.7132$ \pm 0.0008 , MSWD 12. Six out of seven samples from the Eskimonæs aplite granite gave an errorchron age of $670 \pm$ $100 \mathrm{Ma}\left(\mathrm{Sr}_{\mathrm{i}}\right.$ c. 0.710; MSWD 50). Both of these ages are much too old to be considered as dating the time of emplacement of the granites in question. Samples from the Kap Buch locality scattered widely in the isotope diagram, and the data do not yield straightforward chronological information.

\section{Discussion and conclusions}

Zircon U-Pb data, although sometimes difficult to interpret in detail, yield ages of about $400 \mathrm{Ma}$ for the different granites. An important result of this study is that not only the undeformed granites cutting the Eleonore Bay Supergroup, but also the foliated granite sheets within the Smallefjord sequence, are of Caledonian age. In view of their setting a mid-Proterozoic age for the foliated sheets would have been an obvious possibility. $\mathrm{Sm}-\mathrm{Nd}$ and $\mathrm{Rb}-\mathrm{Sr}$ isotope data do not yield further chronological information but, together with other geochemical information, they give clues to the petrogenesis of the rocks.

Sm-Nd isotope studies of Phanerozoic granitic rocks have shown that, with few exceptions, such rocks contain large components derived from older crustal rocks (e.g. Allègre \& Ben Othman, 1980; Hamilton et al., 1980; Gray, 1984). Our isotope data show that this is also the case for the Caledonian granites we have studied from East Greenland, and the major and trace element data (peraluminous character, high $\mathrm{K} / \mathrm{Na}$, high $\mathrm{Rb}$; Table 1 , Fig. 3) are consistent with this contention. However, the structure of the pre-Caledonian crust in the present area is very complex, with rock units varying in age from Archaean to late Proterozoic, and a quantitative interpretation of the composition of the granites is therefore difficult.

From Nd isotope evidence, two petrogenetic models can be suggested for the granites in question (cf. Fig. 5).

(1) The granites represent mixtures of components derived from the mantle and from the surrounding early Proterozoic basement. Analysed basement gneisses (Kalsbeek et al., 1993) had $\varepsilon$ values of $c .-15$ to $-27,400$ Ma ago (Fig. 5). Mantle-derived magmas with positive $\varepsilon$ values, mixed with crustal melts with strongly negative $\varepsilon$ values could have produced the granites in question.

(2) Alternatively, the Nd-isotope data would permit an origin by melting of metasediments of the Smallefjord sequence. We have no Nd-isotopic data on these rocks, but they contain large proportions of $c .1050 \mathrm{Ma}$ old as
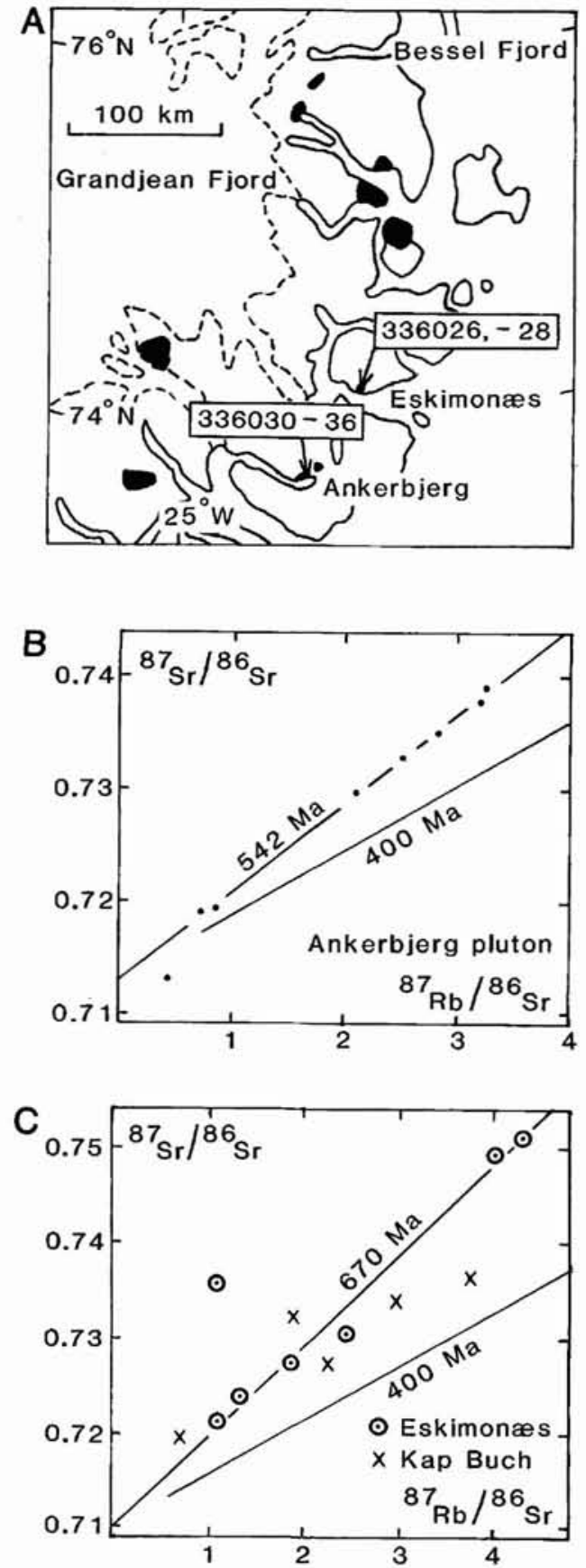

Fig. 6. A: Sketch map showing the location of the Ankerbjerg and Eskimonæs granites for which $\mathrm{Rb}-\mathrm{Sr}$ isochron data were collected. Caledonian granites shown in black. $\mathrm{B}$ and $\mathrm{C}: \mathrm{Rb}-\mathrm{Sr}$ isochron diagrams. The $400 \mathrm{Ma}$ isochron lines are shown for reference only.

well as older detrital zircons (Strachan et al., in press), and the presence of $c .1000 \mathrm{Ma}$ granites further south in the Caledonian belt is well documented (Rex \& Gledhill, 
1981). In Figure 5 an estimate is given of the Nd-isotopic composition of the metasediments, assuming an origin by erosion of c. $1000 \mathrm{Ma}$ granitoid rocks mixed with older crustal material, and Sm-Nd ratios of the same order as for early Proterozoic granitoid gneisses. The analysed Caledonian granites fall within this field, and an origin by remobilisation of such middle Proterozoic rocks (without involving a mantle-derived component) would therefore be compatible with their $\mathrm{Nd}$ isotopic composition. Field evidence for anatectic melt formation within the Smallefjord sequence (Friderichsen et al., 1994) supports the second model for some of the granites. However, it is not likely that the high-Sr granites mentioned earlier have been formed by melting of middle Proterozoic sediments:

Table 5. Rb-Sr isotope data for three Caledonian granite complexes, North-East Greenland

\begin{tabular}{|c|c|c|c|c|c|}
\hline $\begin{array}{l}\text { Locality } \\
\text { GGU No }\end{array}$ & $\begin{array}{c}\mathrm{Rb} \\
(\mathrm{ppm})\end{array}$ & $\begin{array}{c}\mathrm{Sr} \\
(\mathrm{ppm})\end{array}$ & ${ }^{87} \mathrm{Rb} /{ }^{86} \mathrm{Sr}$ & ${ }^{87} \mathrm{Sr} /{ }^{86} \mathrm{Sr}$ & $\mathrm{Sr}_{400}$ \\
\hline \multicolumn{6}{|c|}{ Kap Buch $\left(75^{\circ} 12^{\prime} \mathrm{N} 20^{\circ} 46^{\prime} \mathrm{W}\right)$} \\
\hline $327901 \mathrm{~B}$ & 234 & 180 & 3.764 & 0.73656 & 0.715 \\
\hline $327902 \mathrm{D}$ & 187 & 785 & 0.690 & 0.71965 & 0.716 \\
\hline $327902 \mathrm{E}$ & 191 & 247 & 2.241 & 0.72720 & 0.714 \\
\hline $327905 \mathrm{H}$ & 188 & 184 & 2.958 & 0.73409 & 0.717 \\
\hline 327905 & 196 & 223 & 2.544 & 0.70356 & 0.689 \\
\hline $327906 \mathrm{O}$ & 160 & 246 & 1.885 & 0.73235 & 0.722 \\
\hline \multicolumn{6}{|c|}{ Eskimonas, aplite granite $\left(74^{\circ} 06^{\prime} \mathrm{N} 21^{\circ} 14^{\prime} \mathrm{W}\right)$} \\
\hline $336026 \mathrm{~B}$ & 168 & 259 & 1.871 & 0.72739 & 0.717 \\
\hline $336026 \mathrm{C}$ & 154 & 328 & 1.360 & 0.72390 & 0.716 \\
\hline $336026 \mathrm{D}$ & 145 & 382 & 1.103 & 0.72128 & 0.715 \\
\hline $336026 \mathrm{E}$ & 149 & 391 & 1.104 & 0.73578 & 0.729 \\
\hline $336028 \mathrm{~A}$ & 162 & 193 & 2.434 & 0.73057 & 0.717 \\
\hline $336028 \mathrm{~B}$ & 232 & 156 & 4.315 & 0.75126 & 0.727 \\
\hline $336028 \mathrm{C}$ & 212 & 153 & 4.031 & 0.74956 & 0.727 \\
\hline \multicolumn{6}{|c|}{ Ankerbjerg pluton $\left(73^{\circ} 43^{\prime} \mathrm{N} 22^{\circ} 45^{\prime} \mathrm{W}\right)$} \\
\hline $336030 \mathrm{~A}$ & 290 & 260 & 3.238 & 0.73781 & 0.719 \\
\hline $336031 \mathrm{~B}$ & 252 & 223 & 3.278 & 0.73927 & 0.721 \\
\hline 336033 & 253 & 346 & 2.123 & 0.72989 & 0.718 \\
\hline $336034 \mathrm{~A}$ & 143 & 480 & 0.861 & 0.71953 & 0.715 \\
\hline $336034 \mathrm{~B}$ & 131 & 517 & 0.731 & 0.71918 & 0.715 \\
\hline $336035 \mathrm{~A}$ & 290 & 328 & 2.562 & 0.73270 & 0.718 \\
\hline $336035 \mathrm{~B}$ & 293 & 297 & 2.857 & 0.73503 & 0.719 \\
\hline $336036 \mathrm{~A}$ & 123 & 863 & 0.412 & 0.71317 & 0.711 \\
\hline
\end{tabular}

$\mathrm{Rb}$ and $\mathrm{Sr}$ analysed by XRF on pressed powder tablets at the Department of Geology. University of Copenhagen. $\mathrm{Rb} / \mathrm{Sr}$ ratios have a precision of $c .1 \%$, but $\mathrm{Rb}$ and $\mathrm{Sr}$ ppm values are estimates only $( \pm 5-10 \%) .{ }^{87} \mathrm{Sr} /{ }^{86} \mathrm{Sr}$ was determined at the Age and Isotope Laboratory, Department of Earth Sciences, University of Oxford, U.K. Isotope ratios have a precision of $c .0 .01 \%$. The $\mathrm{Sr}$ standard NBS987 gave average results of 0.71045 for ${ }^{87} \mathrm{Sr} /{ }^{86} \mathrm{Sr}$, which is higher than the accepted value of 0.710248 , and the results have been corrected accordingly. $\mathrm{Sr}_{400}$ represents the ${ }^{87} \mathrm{Sr} /{ }^{86} \mathrm{Sr}$ ratio 400 Ma ago.
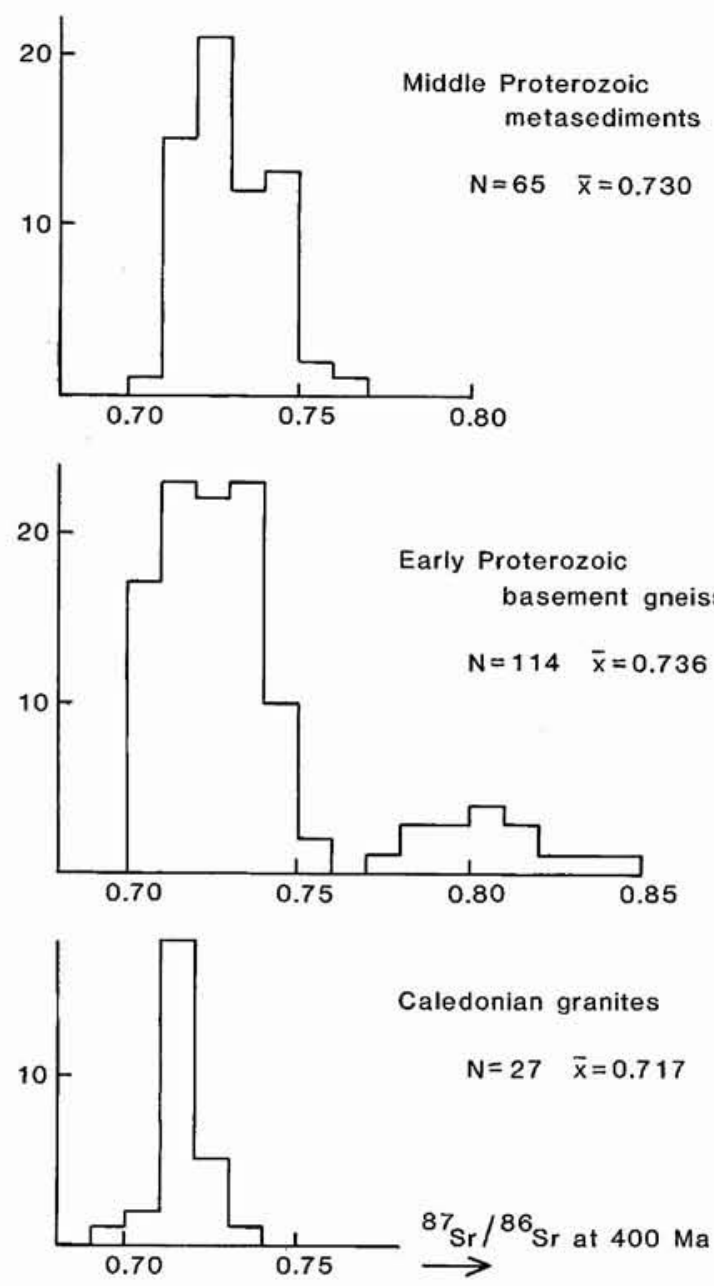

Fig. 7. Sr-isotopic composition of investigated Caledonian granites $400 \mathrm{Ma}$ ago compared with early Proterozoic basement gneisses and middle Proterozoic metasediments. See text for discussion. Data for Proterozoic rocks from Rex \& Gledhill (1981) and Kalsbeek et al. (1993).

these have much lower $\mathrm{Sr}$ (rarely > $300 \mathrm{ppm}$; Rex \& Gledhill, 1981).

${ }^{87} \mathrm{Sr} /{ }^{86} \mathrm{Sr}$ ratios of the analysed granite samples, recalculated $400 \mathrm{Ma}$ backward in time (i.e. at the approximate time of emplacement of the granites; $\mathrm{Sr}_{400}$ ), are compared in Figure 7 with $\mathrm{Sr}_{400}$ values for early Proterozoic basement gneisses and middle Proterozoic metasediments (analyses from Rex \& Gledhill, 1981, and Kalsbeek et al., 1993). Caledonian granites have on average lower $\mathrm{Sr}_{400}$ values (between 0.71 and 0.73 , mean 0.717 ) than the middle Proterozoic metasediments $\left(\mathrm{Sr}_{400}\right.$ mainly 0.710.75 , mean 0.730 ). This difference in $\mathrm{Sr}_{400}$ values does not support an origin of the granites by melting of the metasediments. The granite from Femdalen (GGU 247305 ) with $\mathrm{Sr}_{400}=0.729$ may be an exception. In fact, 
this sample was collected from a granite sheet in the Smallefjord sequence.

Early Proterozoic gneisses have a wide range in $\mathrm{Sr}_{400}$ values (0.70-0.85, mean 0.736; Fig. 7). Mixing of high- $\mathrm{Sr}_{400}$ melts derived from the basement, with low- $\mathrm{Sr}_{400}$ (c. 0.703) magma derived from the mantle in relation to Caledonian orogenic processes, could plausibly yield Caledonian granites with the observed $\mathrm{Sr}_{400}$ values.

The divergence in composition between various granite samples can be explained by differences in the proportions and composition of the crustal component in the rocks. For example, for the samples used in the isochron diagrams of Figure 6 there is a correlation between $\mathrm{Sr}_{400}$ values and $\mathrm{Rb} / \mathrm{Sr}$ ratios. This is why the errorchrons give erroneously high ages. Apparently the higher $\mathrm{Rb} / \mathrm{Sr}$ samples contain larger proportions of Rb-rich old crustal material.

Among the six samples for which we have Sm-Nd and $\mathrm{Rb}-\mathrm{Sr}$ data as well as chemical analyses there is a distinct relationship between several analytical parameters. As mentioned earlier the three samples with $\mathrm{T}_{\mathrm{DM}}>1.4 \mathrm{Ga}$ have higher $\mathrm{Rb}$ and lower $\mathrm{Sr}$ than samples with lower $\mathrm{T}_{\mathrm{DM}}$. The high $\mathrm{T}_{\mathrm{DM}}$ samples also have higher $\mathrm{SiO}_{2}$, lower $\mathrm{K} / \mathrm{Rb}$, and higher $\mathrm{Rb} / \mathrm{Zr}$. They probably contain a larger proportion of crustal components than the other three samples. Sample 247305 from Femdalen, mentioned above, may almost exclusively consist of reworked crustal material.

To summarise, zircon U-Pb data and, for some of the granites, cross-cutting relationships show that the investigated granites were emplaced in Caledonian time, about $400 \mathrm{Ma}$ ago. Sm-Nd and $\mathrm{Rb}-\mathrm{Sr}$ data demonstrate that they are of mixed origin; both mantle derived and crustally derived components are present, and differences in chemical and isotopic composition between individual samples can be explained as the result of variable proportions and composition of the crustally derived component. Apparently the resulting magmas were not perfectly homogenised, and dating by the $\mathrm{Rb}-\mathrm{Sr}$ whole rock isochron method was therefore not successful. U-Pb dating with the help of multi-grain zircon fractions yields ages from 432-396 Ma for individual intrusions, but commonly there is evidence for the presence of minor proportions of older zircon, which, in some cases, complicates precise interpretation of the zircon $\mathrm{U}-\mathrm{Pb}$ data.

Acknowledgements. The isotope data described in this paper were acquired at the Zentrallaboratorium für Geochronologie, University of Münster (Germany), at the Age and Isotope laboratory, Department of Earth Sciences, University of Oxford (U.K.), and at the Department of Geology, University of Copenhagen, Denmark. We thank the staff of these laboratories for support and technical assist- ance. F. K. wishes to express his gratitude to Stephen Moorbath and Paul Taylor in Oxford for long-standing encouragement and cooperation, and Caroline Fry and Roy Goodwin for help with the analytical work. The laboratories in Copenhagen involved in this work are supported by the Danish Natural Science Reasearch Council (SNF).

\section{Appendix 1: Sample descriptions}

GGU 247305, Femdalen ( $\left.75^{\circ} 18^{\prime} \mathrm{N}, 21^{\circ} 35^{\prime} \mathrm{W}\right)$.

Collectors R. A. Strachan \& J. D. Friderichsen.

Massive c. $100 \mathrm{~m}$ thick concordant sheet of white foliated granite in the Smallefjord sequence. Forms part of a series of anastomosing sheets, some of which lack foliation.

GGU 247354 , Langsø $\left(75^{\circ} 49^{\prime} \mathrm{N}, 20^{\circ} 34^{\prime} \mathrm{W}\right)$.

Collectors R. A. Strachan \& J. D. Friderichsen.

From a foliated gneissic sheet complex emplaced slightly discordantly into Smallefjord sequence metasediments. These foliated granitoid sheets and the adjacent gneissic supracrustals are cut by numerous, late, non-foliated aplitic veins. The chemical analysis (Table 1) with only $58 \% \mathrm{SiO}_{2}$ and $9 \% \mathrm{~K}_{2} \mathrm{O}$ indicates a distinct alkali syenitic composition, different from the other analysed Caledonian intrusions.

GGU 247355, Langsø $\left(75^{\circ} 49^{\prime} \mathrm{N}, 20^{\circ} 24^{\prime} \mathrm{W}\right)$.

Collectors R. A. Strachan \& J. D. Friderichsen.

Aplite from a large subconcordant, but clearly late intrusive sheet in banded psammitic gneiss of the Smallefjord sequence. The sample was taken c. $4 \mathrm{~km}$ east of GGU 247354.

\section{GGU 279515, Kap Klinkerfues granite ( $\left.75^{\circ} 17^{\prime} \mathrm{N}, 20^{\circ} 38^{\prime} \mathrm{W}\right)$.}

Collector A. K. Higgins.

Large pluton, 7-8 km across, cutting sharply across major folds in the Eleonore Bay Supergroup. A medium to coarse grained, unfoliated, leucocratic two mica granite, which may be connected with the major sheet-like complex on the south side of the fjord.

\section{GGU 294921 , Knæks $\emptyset$ granite $\left(75^{\circ} 51^{\prime}\right.$ N, $\left.21^{\circ} 49^{\prime} \mathrm{W}\right)$.}

Collectors M. Sønderholm and H. Tirsgaard.

From the larger of two granite stocks which cut sharply through flat-lying units of the lower Eleonore Bay Supergroup at the eastern end of Knæks $\emptyset$. The bodies are rather homogeneous, but contain inclusions of the host rocks especially in the marginal zones. The rock is a two-mica granodiorite with a coarse grained, porphyritic texture.

GGU 294939, Bredefjord granite (75³9' N, $\left.22^{\circ} 17^{\prime} \mathrm{W}\right)$.

Collectors M. Sønderholm \& H. Tirsgaard.

Large granite stock, about $4.5 \times 7.5 \mathrm{~km}$ across, intruded into the lower Eleonore Bay Supergroup (Nathorst Land Group; Sønderholm \& Tirsgaard 1993). The intrusion outcrops on both sides of the glacier at the head of Bredefjord and is well exposed at the steep sides of the fjord and glacier (Fig. 2). The contacts are generally sharp and usually quite regular, but in places with aphophyses into the sediments. Large enclaves of sedimentary rocks occur locally in the granite. Haller \& Kulp (1962) reported 
a K-Ar muscovite age of $394 \mathrm{Ma}$ from this intrusion. The analysed sample comes from a pegmatitic variety of a two mica granite.

GGU 327870 , Granite west of Knaksø $\left(75^{\circ} 50^{\prime} \mathrm{N}, 22^{\circ} 22^{\prime} \mathrm{W}\right)$. Collector N. Henriksen.

Small plug of homogeneous medium grained biotite granite with aplitic veins, cutting folded and metamorphosed (epidoteamphibolite facies) Eleonore Bay Supergroup metasediments.

GGU 327901, $-902,-905,-906$. Granite samples from the Kap Buch complex $\left(72^{\circ} 12^{\prime} \mathrm{N}, 20^{\circ} 46^{\prime} \mathrm{W}\right)$.

Collectors: J. Kusz \& N. Henriksen.

Homogeneous, non-foliated, medium grained two mica granitic samples from the large heterogeneous complex cutting Eleonore Bay Supergroup sediments south of Ardencaple Fjord.

\section{Appendix 2: Analytical methods}

The whole-rock zircon populations were fractionated according to grain size. Extraction of $\mathrm{U}$ and $\mathrm{Pb}$, spiking, and massspectrometric procedures were carried out according to the method described by Persson et al. (1983). The $\mathrm{Pb}$ data were corrected for initial $\mathrm{Pb}$ and analytical blank. The isotopic composition of the initial $\mathrm{Pb}$ was calculated corresponding to an age of $425 \mathrm{Ma}$ according to the model of Stacey \& Kramers (1975).

The analytical total $\mathrm{Pb}$ blank was in the range of 0.5 to $1.0 \mathrm{ng}$ $\left({ }^{208} \mathrm{~Pb} /{ }^{04} \mathrm{~Pb}=37.7,{ }^{207} \mathrm{~Pb} / 204 \mathrm{~Pb}=15.52,{ }^{206} \mathrm{~Pb} /{ }^{204} \mathrm{~Pb}=17.72\right)$. The ages were calculated using the constants recommended by the I.U.G.S. (Steiger \& Jäger, 1977). Calculation of errors and error correlations of the ${ }^{206} \mathrm{~Pb} /{ }^{38} \mathrm{U}$ and the ${ }^{207} \mathrm{~Pb} /{ }^{35} \mathrm{U}$ ratios were carried out according to Ludwig (1980), taking into consideration the errors of measured isotopic ratios, the uncertainties of the $\mathrm{U} / \mathrm{Pb}$ ratio in the mixed spike, the error magnification due to the spike/sample ratio, and errors arising from uncertainties of blank and common $\mathrm{Pb}$ correction. The error assigned to the ${ }^{207} \mathrm{~Pb} /{ }^{204} \mathrm{~Pb},{ }^{206} \mathrm{~Pb} /{ }^{204} \mathrm{~Pb}$ and ${ }^{206} \mathrm{~Pb} /{ }^{204} \mathrm{~Pb}$ initial and blank $\mathrm{Pb}$ isotopic composition is $1 \%$. The correlation factor for initial and blank $\mathrm{Pb}$ is 0.7 . The error ellipses on the concordia diagrams were drawn for a $95 \%$ confidence level. The discordia lines were calculated according to the least squares method (York, 1969) using the Geodate calculation program (Eglinton \& Harmer, 1991) for regressions and graphics.

\section{References}

Allègre, C. J. \& Ben Othman, D. 1980: Nd-Sr isotopic relationship in granitoid rocks and continental crust development: a chemical approach to orogenesis. Nature 286, 335-346.

Dallmeyer, R. D. \& Strachan, R. A. $1994:{ }^{40} \mathrm{Ar} /{ }^{39} \mathrm{Ar}$ mineral age constraints on the timing of deformation and metamorphism, North-East Greenland Caledonides. Rapp. Gronlands geol. Unders. 162 (this volume).

Dallmeyer, R. D., Strachan, R. A. \& Henriksen, N. 1994: ${ }^{40} \mathrm{Ar}{ }^{39} \mathrm{Ar}$ mineral age record in NE Greenland: implications for tectonic evolution of the North Atlantic Caledonides. $J$. geol. Soc. Lond. 151, 615-628.

DePaolo, D. J. 1981: Neodymium isotopes in the Colorado
Front Range and crust-mantle interaction in the Proterozoic. Nature 291, 193-196.

Eglinton, B. H. \& Harmer, R. E. 1992: Geodate. A program for processing and regression of isotope data using IBM-compatible microcomputers. CSIR Manual EMA-H 9101, 57 pp.

Faure, G. 1986: Principles of isotope geology, 589 pp. New York: John Wiley and Sons.

Friderichsen, J. D., Henriksen, N. \& Strachan, R. A. 1994: Basement-cover relationships and regional structure in the Grandjean Fjord - Bessel Fjord region $\left(75^{\circ}-76^{\circ} \mathrm{N}\right)$. Rapp. Grønlands geol. Unders. 162 (this volume).

Gray, C. M. 1984: An isotopic mixing model for the origin of granitic rocks in southeastern Australia. Earth Planet. Sci. Lett. 70, 47-60.

Haller, J. 1971: Geology of the East Greenland Caledonides, 413 pp. New York: Interscience Publishers.

Haller, J. \& Kulp, J. L. 1962: Absolute age determinations in East Greenland. Meddr Grønland 171(1), $77 \mathrm{pp}$.

Hamilton, P. J., O'Nions, R. K. \& Pankhurst, R. J. 1980: Isotopic evidence for the provenance of some Caledonian granites. Nature 287, 279-284.

Hansen, B. T. \& Friderichsen, J. D. 1987: Isotopic age dating in Liverpool Land, East Greenland. Rapp. Gronlands geol. Unders. 134, 25-37.

Hansen, B. T. \& Steiger, R. H. 1976: The geochronology of the Scoresby Sund region, central East Greenland. Progress report 7: Rb-Sr whole rock and U-Pb zircon ages. Rapp. Gronlands geol. Unders. 80, 133-136.

Hansen, B. T. \& Tembusch, H. 1979: Rb-Sr isochron ages from east Milne Land, Scoresby Sund, East Greenland. Rapp. Gronlands geol. Unders. 95, 96-101.

Hansen, B. T., Steiger, R. H., Henriksen, N. \& Borchardt, B. 1987: $\mathrm{U}-\mathrm{Pb}$ and $\mathrm{Rb}-\mathrm{Sr}$ age determinations on Caledonian plutonic rocks in the central part of the Scoresby Sund region, East Greenland. Rapp. Gronlands geol. Unders. 134, 5-18.

Henriksen, N. 1985: The Caledonides of central East Greenland $70^{\circ}-76^{\circ}$ N. In Gee, D. J. \& Sturt, B. A. (ed.) The Caledonide orogen - Scandinavia and related areas, 1095-1113. Chichester, U.K.: John Wiley and Sons.

Kalsbeek, F., Nutman, A. P. \& Taylor, P. N. 1993: Palaeoproterozoic basement province in the Caledonian fold belt of North-East Greenland. Precambrian Res. 63, 163-178.

Ludvig, K. R. 1980: Calculation of uncertainties of U-Pb isotope data. Earth planet. Sci. Lett. 45, 212-220.

Pearce, J. A., Harris, N. B. W. \& Tindle, A. G. 1984: Trace element discrimination diagrams for the tectonic interpretation of granitic rocks. J. Petrol. 25, 956-983.

Persson, P.-O., Wahlgren, C.-H. \& Hansen, B. T. 1983: U-Pb ages of Proterozoic metaplutonics in the gneiss complex of southern Värmland, south-western Sweden. Geol. Fören. Stockh. Förh. 105, 1-8.

Rex, D. C. \& Gledhill, A. R. 1981: Isotopic studies in the East Greenland Caledonides $\left(72^{\circ}-74^{\circ} \mathrm{N}\right)$ - Precambrian and Caledonian ages. Rapp. Grønlands geol. Unders. 104, 47-72.

Sønderholm, M. \& Tirsgaard, H. 1993: Lithostratigraphic framework of the Upper Proterozoic Eleonore Bay Supergroup of East and North-East Greenland. Bull. Gronlands geol. Unders. 167, $38 \mathrm{pp}$. 
Stacey, J. S. \& Kramers, J. D. 1975: Approximation of terrestrial lead isotope evolution by a two-stage model. Earth Planet. Sci. Lett. 26, 207-221.

Steiger, R. H. \& Jäger, E. 1977: Subcommission on geochronology: Convention on the use of decay constants in geo- and cosmochronology. Earth Planet. Sci. Lett. 36, 359-362.

Steiger, R. H., Hansen, B. T., Schuler, C., Bär, M. T. \& Henriksen, N. 1979: Polyorogenic nature of the southern Caledonian fold belt in East Greenland: an isotopic age study. J. Geol. 87, 475-495.
Strachan R. A., Nutman, A. P. \& Friderichsen, J. D. in press: SHRIMP U-Pb zircon geochronology of the Smallefjord (metasedimentary) sequence: implications for crustal history and structure of the NE Greenland Caledonides. J. geol. Soc. Lond.

Streckeisen, A. L. 1976: To each plutonic rock its proper name. Earth Sci. Rev. 12, 1-33.

York, D. 1969: Least-squares fitting of a straight line with correlated errors. Earth Planet. Sci. Lett. 5, 320-324. 